\title{
ON THE WORDING OF IMAGES AND DISPERSION: POE'S BREATHING METHOD. A CANVAS AND DIALECTIC OF FLOWING WATERS WITHIN
}

\author{
Julio Ángel Olivares Merino.Universidad de Jaén
}

\section{ABSTRACT}

This essay, not an evaluative but a descriptive, inspecting and interpreting one, intends to theorize about the cognitive hallmarks within Edgar Allan Poe's fictional universe of nemesis, rhetorical grotesque semantics, foregrounded and highlighted macabre philosophical vestiges, both in terms of the constants and prisms playing a fundamental role in his encoding creative process depicting reality -context of utterance- and productively transforming it into an abiding and refuge-like paradise of the ineffable -context of reference-, as well as on the significant choices and pragmatic maxims involved in his gradual and methodic regression into madness as a purely literary and individual quest for the Sublime. The lines that follow are also impelled, as a second articulation of our proposition, to provide the reader with some of the most prominent and notorious features in Poe's prose and poetry: his patterns of impact and scars of defamiliarization, his peculiar and obsessive delineation of sequenced states heading for the last glimpse of unity after self-annihilation, the disciplined wording or orchestration of microeffects towards the knowledge of the Absolute, aiming to establish a parallelism between the different seasons covering the envisioning of the innerly maturing self and the explicit pattern of dawning colours that founds the definition of the erotically desirable, the mannequin of the supernal or macroeffect of everlasting existence categorized by inner metaphors and intrinsically artistic inventions.

We all know that art is not the truth. Art is a deception made in order to approach the truth, at least such as can be expressed. The artist has to find a way to convince others of the truth through his deception. (...) "Truth" is found beyond the canvas, never in it. It is realized in the relationship of the canvas with reality. (Picasso)

It is true that I may not find an opportunity of transmitting it [the journal] to the world but I will not fail to make the endeavour. At the last moment I will enclose the MS. in a bottle, and cast it within the sea. (Poe, 1986: 105-106) 


\title{
1. AN OVAL FRAME FOR A WORLD THAT CHIMES TO EXTINCTION. PERTURBATION, PESSIMISM AND OTHER PROSPECTIVE IDEALIZATIONS
}

\author{
They can only shriek, shriek / Out of tune (Poe, 1986: 92)
}

In such fragrance of doomed nostalgia Poe drowned out the titillating chime of bells, exclaiming to be drained of lust and conquering desires, laying hopes in the shroud of postrerous silence coming to cast a dormant spell on existence. And when passionately describing the horror he was thinking about, when deciphering the oppressive textures of reality, the vast oceans, the skies torn asunder, the poet, as the eternal observer and observed, sighed in his pulpit of oracles, buried alive in the cellar of an ivory tower, cremated by solitude, decomposing in the rhymes of shades, of dawns and nightfalls.

There was always, for Poe, a spell of macabre and bizarre inertia -like that in the ineffable waving of his diegetic pendulum- in the flow of existence. Death was lurking everywhere, willing to improvise a blind tapestry or shroud for its prey. The empiric idea of transitivity and causality -the constancy of something happening to someone because of a particular action employed by a particular agent- was diffused into a random horrendous anarchy that was, in fact, a conviction based on the announced prophecy that guided each soul in the consumptive enactment of life. Breaking the logic of free will ${ }^{1}$ and free consequence brought the disclosure of evergrey melancholy, tears and pain that stood for the terse presagio of a gust of disgrace in a life wandering towards extinction, no matter how one challenged destiny. The implications of this prolonged waiting for shivers born in Poe's self definitely reverberated in his fables of fading galleries and picturesque agony from the cradle to the grave.

Once happenings followed the edicts of misfortune as well as the uncontrollable impulse of the perverse -"the prima mobilia of the human soul (...) existing as a radical, primitive, irreducible sentiment" (Quoted in Bloom, 1998: 23) -, in the doomed proscenio of predestiny and intransitivity there appeared for the poet only landscapes of announced ruin, wandering silhouettes, whispers, the ghastly freezing moon and, of course, the often by-passed inhabitants of our minds, victims and victimizers, those aliens of ours.

Transitivity was not valid for Poe, but ubiquitous ambiguity surely was; floating in the air and being the air at the same time, being not only suspended in an expectation of disgrace but also representing fatality, embracing the supreme and being drowned in its eventual absence or loss, was all one. Time compressed in a vacuum of annihilation seeds, leaving no concept in its essence, no trace of seasons, no diachronic breath, as phases in a life were annuled and shaded by the predicted hindermost desillusion. The poet should consequently find a hole, an abyss, in that pain of the never, in the desperation of being alienated and dispersed by the lack of room to materialize before extinction and, once in the shelter, in the embroidering shell or shut-in paradise of the spirit -being the quintessential outsider inside-, be impelled to look at time from within, taming its passing currents, leaving a dying candle in the outside, in reality, announcing that there was a soul in pain, letting lines and verse flow through that porous hole from the inside, from the inner dimension -the

\footnotetext{
1 The dark half, a dooming attraction, will finally engulf us. We are all steps heading for the postrerous threshold where a last tinge of evil baptizes us dead, whatever we may have done in life. William Wilson laments:

I fled in vain. My evil destiny pursued me as if in exultation (...) From his inscrutable tyranny did I at length flee, panick-stricken, as from a pestilence; and to the very ends of the earth I fled in vain. (Poe, 1986: 175)
}

Odisea, $n^{\circ}$ 2, 2002 
purgatory of meditation-, where the poet's soul searched for balance and identity, and prevented his senses from coming back to the ashes of conventional context where they were likely to waste away.

For Poe, life was, consequently, just the intransitive action of fate, the constant sound of untuned bells, and the unfleshed hand of femininity forced to toll them in dark landscapes whereas will was the seizing of instants, the flowing of the mind into that hole of the self, into the core of imagination, where existence would be justified and "felt" as one's own while being dissected. This process of acknowledgement of limitations, embracing of shadows, was, in itself, an allegory for the ritualized re-entering the maternal womb as a logical necessity to be, once again, sheltered in unity and origin.

In Eureka we find instances of this bound-to-the-past-or-the-primitive obsession in Poe: "Let me declare, only, that as an individual, I myself feel impelled to fancy - without daring to call it more - that there does exist a limitless succession of Universes, more or less similar to that of which we have cognizance (...)Each exists, apart and independently, in the bossom of its proper and particular God" (quoted in Bloom, 1998: 36). Transcendentalist epitaphs and revelations of a God-centred conception of existence impregnate this morality play about a lost world ${ }^{2}$, a lightning era of terminal scars, the picture of a tragedy constantly renewed and sketched. In Edward H. Davidson's words:

The poem, therefore, demonstrates Poe's growing pictorial necessity: abstractions and ideas become translated into tableaux, a set of stylized and formalized pictures which enact the drama. The mind is a castle; the sovereign is Thought; the

\footnotetext{
2 Lots of menaced desert worlds, landscapes inhabited by phantoms and enshrouded by the tupid mists of misery, realms of lost calmness now heading for their dissolution, haunted Poe's mind as reflections of both his turbulent existence, his present, and breathless anticipations of the final rest. These besieged universes of lost purity, of whiteness turned ochre, territories of the Apocalipsis, were the materialization of abandonment and decay, the haunted palace in "The Fall of the House of Usher", governed by "Thought" and "radiant" angels from the past, now in the flames of black art. Notice the contrast between the first stanza, a glittering of hopes and the stigmata revealed in the last lines, showing the result of a withered essence in which smile is not alive anymore, a transfer that is the basis for our analysis:
}

$$
\text { I }
$$

In the greenest of our valleys,

By good angels tenanted,

Once a fair and stately palace -

Radiant palace -reared its head.

In the monarch Thought's dominion-

It stood there! (...)

\section{V}

But evil things, in robes of sorrow, Assailed the monarch's high state (...)

And, round about his home, the glory

That blushed and bloomed

Is but a dim-remembered story

Of the old time entombed. (Poe, 1986: 147-48)

These palaces of doom facing the abyss were converted into allegorical proscenios where warring tendencies performed the psychomaquia. The diffuse stage of helpless and mute angels in "The Conqueror Worm" (1843) together with the adimensional silence, the out-of-space-and-out-of-time night in "Dream-Land" (1844) are neat examples of these paradises of devastation, settings deprived of God's intervention, where mimic doomed puppets dwell in darkness.

Odisea, $\mathrm{n}^{\mathrm{o}} 2, \quad 2002$ 
windows are eyes; the attendant ideas are Echoes and graces and the inimical world of reality outside, which for a time exists in complete subservience to the will of Thought, finally overwhelms and destroys the mind. (1976: 80)

For the poet, reality spins from unity to diversity, forming particulars in a profane state before finally being reunited by God, who, employing a natural ritual, must eventually, in the perpetual cycle of births and decease, disperse everything in new spiritual and material manifestations. A longing for dissolution and death -the doomed end and the ashes of a new beginning- for subsequent perfection, a further unity, was then fundamental for Poe. In fact, he considered hilarity and happiness -semblants of Pureness and Perfection- were to be described, reached, interpreted and embraced only after agonizing trances. All in all, Poe's quest for the possession of ideals was concretely materialized in an aspiration towards Beauty: "the sole legitimate province of the poem (...), not a quality, as is supposed, but an effect (...), that intense and pure elevation of soul" (Poe, 1986: 483).

If in his cosmology, God, as eternal commander and ruler of the wandering sinners, used to recreate the universe by an explosion of benevolence and inspiration after assuming the comatose state of mind and the phantasmagoric silence of decaying worlds, the poet, another vigilant deity, had the patience and capacity to witness the gradual nightfall coming to a heaven naturally provided in birth and later becoming a hellish land of chaos, the rotting paradise lost, so as to reign over disaster. Art was, for Poe, the unique method by which one could penetrate the ethereal world of experience to bring order. The demiurgic chimera, the composer of lines had, as a consequence, a mission in life, the self abstraction and discovery of dark tendencies, of sentenced wishes, the versification of sighs heading for dissolution, in a word, the colouring of maddening loss.

By enchanting fallen grace, frustrated aspiration and tortuous pain, Poe managed to frame the unsubstantial texture of doom, leading us -with murmurs of morbid shrieks and dungeon shouts in the background- through the threshold of his grotesque fiction about the terrors of the soul and the consuming misfortune of melancholy, finally founding the apex of emotions. Step by step, tear by tear, in crescendo, scanning the errant beatings of a turbulent mind and skimming the visions of schizo, he recreated the cry of mankind and the mirrored deviations of individuals. Poetry -defined by Leech (1969: 12) as "the mode of composition which is creative par excellence"- was for him a means of providing the reader with the intimacy of this staged ritual towards the adoption of Beauty, from the cold sight of the eye of the vulture -in "The Tale-Tell Heart"-, the trances of sudden strokes of fate, until "the intoxication of the Heart", as he called the last outcome or dénouement of states of causality:

It [Beauty] is the desire of the moth for the star. It is no mere appreciation of the Beauty before us - but a wild effort to reach the Beauty above. Inspired by an ecstatic presence of the glories beyond the grave, we struggle, by multiform combinations among the things and thoughts of Time, to attain a portion of that Loveliness whose very elements, perhaps, appertain to eternity alone. (Quoted in Galloway, 1986: 17)

He chose to portray suffering, always feeling pain as the primal justification of what was to be described and told afterwards with landscapes born in diffused vortexes of the unknown, coming from a desolate darkness, turning into carved pentagrams of nostalgia 
and confession, silvery symphonies of absence, preluded death, disdain and abandonment, which at the end constituted the ectoplasmatic semblance of those mental representations of the intangible.

If music was for Poe the supreme art form, the most privileged sigh to apprehend supernatural Beauty -"as mere mortals, we are as yet in no condition to banquet upon those supernal ecstasies of which the music affords us merely a suggestive and indefinite glimpse" (Poe, 1986: 433) -, it is also true that the conscious juxtaposition of his pictorial hymns, composed by emotive notes and traces, describes, in an accurately graphic way, the anxiety and wandering bound to the enjambments of shadows.

Landscapes, as Poe knew, are ubiquitous, like serpentine emotions besieging our limitations, like the banshee-like cry within: landscapes of eras, physical remnants, landscapes of the lived, of the imagined, of the enjoyed, landscapes of the mind, of the self, aureoles lost in preludes of dusk or degradations still and forever dying in grey; all of them, landscapes of the present, elusive or crowned mists of the past, tears of a longed fate that may remain within ourselves like skies of decay, fading to black, landscapes of absence through the enslaving passing of time. Poe's poems definitely fall into the concept of imagery -"pictures, statues, optical illusions, maps, diagrams, dreams, hallucinations, spectacles, projections, poems, patterns, memories, and even ideas as images" (Mitchell, 1980: 9) -, a cluster of phenomena gathering the visual essence of an icon as well as the systematic description of a state through the figuratively exposed.

Tonalities happen to rust. Someone, however, the American writer's utopic mind seemed to murmur, must remain to mourn, to unveil the creeping misfortune, to exhale the constant pace of tyranny and lay a trembling hand on the rained silence, to compose the bible of winds, the emotive imagery of the alien self captivated inside. Pain is not for the absent, for the pale buried in oblivion, but for those who thirst for the touch. Actually, as a conscious sleepwalker, Poe chose to cross the abyss, submerging in the depths of madness, mathematically tracing the paths into the away-in-us, departing from the depressed state of mind, theorizing about any human constraint, painting on the universal glass, to overcome particular annihilating trances of the individual and gain the freedom of Perfection. Description, intense ramification of senses and states, craving of metaphors, his illuminating pictures -"a succession of brief ones -that is to say, of brief poetical effects" (Poe, 1986: 482)-, enfeebled microeffect canvases so as not to interfere with the climactic effect.

It is, on the other hand, inferred from that imaginary path and the seeds of beatings in a vacuum -which, as a whole, constituted Poe's existence- that he was probably the zenit of the romantic masquerade and letany of grotesque gothic dreams in the nineteenth century. His portrait is that of a weak, anorexic and melancholic semblant, a vacant stare -over a balanced moustache, a conventional gravely polite expression- at the depths of time, a hypothetical frame in which the echoes of his memories perceived the protean metaphor of ulterior human tragedy, a space we, as readers, inhabit. Concretely remarking, in the revelation of opium -the extremely sensitive and sensible afection of Atentas and the murmurs of a doomed fall from grace, a descent into the depths of desperation-, the American author webbed the everlasting formula of depression, lust, damnation, solitude, death and raging impelling hunger for selfdestruction, dark waves of madness and hysteria that burned a stigma of gloominess under the agonizing trance of his lines and the lethal tranquility of his catacomb tales: 
He murders only to incur his own destruction. (...) The conscience, the 'other' William Wilson, preys on the ego and precipitates the final disintegration of the personality. (Walker, 1993: 120)

Preserved, with a frozen warmth of permanent remembrance inside, Poe converted his poetic chantings of nemesis into a frame which portrayed the distressful metaphors and effigies of doom, constantly remodelling the same scent of chrysanthemums, mesmerized by the iterative announcement of the recurrent nightmares of decay. His description was in the feverish obsession of touching, feeling and representing the dead forms- so mysanthropic that objective echoes of beauty could not just reach further than his own honest cries. Most often, his depiction craved the epitaph of a one-way transfer to the underworld of the self and, in the coven of catharsis, his narrative lost fluidity and contextual freshness. When stained with the statism of elongated descriptive pauses, his apperceptive emplottment was monopolized by feeling and the impish stream of consciousness, a self-contained enactment. Poe's narratives reveal a serial description which becomes sui generis art and, intending to be a means, also becomes an end, as Hamon would put it:

[T]he more it [narrative] becomes saturated with descriptions, the more it is concomitantly forced to multiply its empty thematics and redundancies, and the more it becomes organized and repetitious, thus becoming increasingly a closed system: instead of being referential, it becomes purely anaphoric; instead of evoking the real ('things' and 'events') it constantly evokes itself. (1982: 170)

Since the skeleton of action is compressed at the very beginning by intuition, following an inductive lightning that illuminates the whole poem, development and destiny being already inferred and expected at the initial post of reading, only the intensification of weird and obscure deep feelings heading for the final state of depravity and desolation -only that search for the edge of insanity and the bathing of the intended effect- are worth being considered and emphasized. As the poet manifested:

Nothing is more clear than that every plot, worth the name, must be elaborated to its dénouement before anything be attempted with the pen. It is only with the dénouement constantly in view that we can give a plot its indispensable air of consequence, or causation, by making the incidents, and especially the tone at all points, tend to the development of the intention. (Poe, 1986: 480)

The foggy trace of an epitaph is the only symptom that may illustrate the emotion under the words, the coherent beating of the anxious heart, the only thing that may still lie at the waveless sea after the storm. If in Poe's sinking universe, tears are inevitably to fall, if all lives and states in his cosmos of doom are a prelude, a genesis and a prologue for a sure destruction of the self and the definite advent of the realm of darkness, masochism in depicting the horrible is the only artistic way of combating desperation, the only alternative to inactive awaiting of the gruesome. With Poe, sighing in darkness becomes a beginning, a medium and an end, a way of existence, a framing guidance rather than a parody of the 
excessiveness and deliria of the Gothic, as some critics have bitterly posed (Broncano, 1996). ${ }^{3}$

Being dynamic and awake meant for Poe leaving no trace of reality on his palms and choosing the dream of fiction as the lake for the moon of desires to beam. Defenseless in the confusing vortex of everything, submerged in the universal, Poe thought it was worth taking advantange of the gloomy solitude, abiding for trances within the core of the individual, the fresh contagion of mediation, in order to benumb the process of decomposition, the involution.

This being so and wanting both to catch the wind and have a glimpse of those crows and fatal sighs crossing the vastness towards him in the nights of the sensible and physical world, he decided to close his eyes to decelerate the pace of the chanting murmurs of the imminent and so dilate the gaze of the foreboding. That would also mean duplicating the pain, but with the purging feeling of being conscious of it, facing destiny and gradually coming into terms with the inevitable, feeling it approaching, feeling oneself diffussing, accepting the doleful answer of time that otherwise, not faced, would suddenly come to deprive one of sense and will.

As we see it, accepting the coming of chaos at a distance means maturing. In Poe, reasoning the worst, justifying it to some extent, implies being true to oneself, being aware, that is, sane and wise in madness. The writer closed his eyes in the conviction that he would "live his own death" instead of suddenly "dying his life" and consequently he opened his heart to the metaphysical ether, wanting to break the enshrouded panes of existence, concentrating on the fearful annunciations of fate, changing the immaterial objective flow of time for his own midnight chiming of plaguing epochs. He decided to be the ash in the eyelid of each spirit, each anonymous narrator -his alter egos-, considering the symbiotic linkage of the real with fiction, his impregnating of the fluids of the living with the metaphor of horror, bringing the threshold of every man to a thoughtful absence, a depiction of his silhouette in the world of visible entities, projecting him as a presence in the labyrinth of mind, where everything should live and take place onwards, until the worst comes. In that solipsistic paradise, reason and desperation collide -self and the text collapse-, forming the new taste and passion of those insane narrators who, almost in every case, assume the role of a yelling conscience fighting to free itself from the ghosts of the past, once it is bound to darkness for a crime commited, ultimately trying to justify its procedure, its methodic and premeditated way of acting, the impulse of the perverse. It is precisely this creative vitality of the remembrance that rules Poe's tales and poems, that makes his thorned world go round...

... since in remembrance came nemesis...

\footnotetext{
${ }^{3}$ John S. Whitley found the eerie ambients and atmospheres of Poe, reflections of psychological turbulent inner states, as a homage-like legacy of the Gothic. Capturing the protean essence of the concept of isolation in siege, Poe brought the storm and lightning inside, creating the night of mind, the shroud of conscience. Thus, he achieved a wonderful revitalization of the vein of the macabre, what Whitley calls "sophistication" rather than degradation, a renewal in which settings of the self and of the universe collapse to form a shire of loss, a marsh of freaks overruled by a genius who is mastered by the touch of Evil. As stated by the critic:

He made more sophisticated elements he took from the European Gothic tradition, such as subterranean dangers, the femme fatale (literally so in 'The Fall of the House of Usher'), burial alive, ghosts, excessive curiosity, the curse from the past, exotic locales, but because he fashioned those elements into a remarkable investigation of abnormal psychological states and obsessional behaviour (what he chose to call 'the imp of the perverse'). (1993: vi-vii)
}

Odisea, $\mathrm{n}^{\mathrm{o}} 2, \quad 2002$ 


\section{THE NOMENCLATURE OF A RAINBOW MASQUERADER. WORD, MURMURS AND THE TOUCHING EFFECTS}

Although similar in pace, intense revelation, structural pattern and equally ruled by the search of a unique and final effect -"Some artistic piquancy which might serve me as a keynote in the construction of the poem -some pivot upon which the whole structure might turn" (Poe, 1986: 484)-, verse and prose marked a boundary of exposition and modi vivendi in Poe's visionary and confessional universe of fiction. His half-beating heart stranded in the middle of nowhere did not resound with the same morbid vitality in the predatory lines of his "arabesques" -an elegy for lost innocence- as compared with the rays of nostalgia abiding in the deep seas of his poems - a cry for lost hope, for an absent diva. While Poe's first-person visioner in the stanzaic wasteland is usually a sufferer betrayed by fate, his prose narrators are puppets of a destiny emanating from the inner fabric of the perverse. The former follows either the steps of an absent lover, a never-forgotten mother, or looks at the moon in an existentialist search for an answer. In fact, the absolute and intended tone of melancholy is besieged and achieved, Beauty being triumphantly enthroned as the object of Purity, as the consumation of the Supreme, even though the subject focalizer, the narrator, is finally deprived of it:

'Of all melancholy topics, what, according to the universal understanding of mankind, is the most melancholy?' Death - was the obvious reply. 'And when,' I said 'is this most melancholy of topics most poetical?' From what I have already explained at some length, the answer, here also, is obvious - 'When it most clearly allies itself to beauty: the death, then, of a beautiful woman is, unquestionably, the most poetical topic in the world - and equally is it beyond doubt that the lips best suited for such topic are those of a bereaved lover. (Poe, 1986: 486)

Poe's poems and love/death tales are the intense repetition of a chilling word, "nevermore" -the most striking and scarring tone of blackness stated by the raven and flouting over the hissing and looming flow of his bizarre portraits-, the lament-like negation of a possible return to reality and light, once the oval niche is definitely constructed and its dark symphonies are revealed:

And ah! let it never

Be foolishly said

That my room it is gloomy

And narrow my bed;

For many man never slept

In a different bed

And, to sleep, you must slumber

In just such a bed. (Poe, 1986: 85)

That reality and lucidity -which once, at the very beginning, seemed to be wet with everlasting tranquility- initially constitute the cradle to be burnt, the dying pulse of a sublime perfection to be dethroned, is clear. His first drafts of visual experience are the summit of a holy and immaculate clarity, the self-confident notes of a silky allegro soon to be torn in the decadent fragility of a musky adagio he would not fail to appreciate. His art is, 
consequently, like the majesty of a lightning that crowns the night and fades to bring a darker solitude, a vast insuflation of perfection and bliss that hides an announced degradation. The structures of Poe's poems and tales are never arbitrary -in fact, he felt nothing in his life was, especially since he was sure fate tended to constantly conspire against him. His creations were indivisible constructs of atoms under the shade of a matter, an effect, organic architectures of parts that were exquisitely ordered, each relating to the whole. His method followed a gradual progression from a universal state to the particular final suffering, achieving the unity of the plot, the supreme cosmic order so expressed in "Eureka", an arrangement which emphasized the prevailing idea. Composition in Poe, then, is an antidiffusing process of intensification which curiously results in thematic decomposition. The "whole", the mystical, is for the poet an assimilated succession of minor portraits, an allegory, a perfectly balanced megapicture or megawindow containing several panes, as well as scratches and fingerprints, several voices combined by imagination in an introspective and somehow heteroglossic journey through textures of insight, like Novalis' hymns of alienation from objective light; it is a wall of paper surrounding the core of a fortress. Every printed word is important for its suggestive charge of epiphanic light or darkness, for its tone or the meaningful event it names, and for its position in the chain.

Before that "whole" came into being -after each step of composition was completed-, Poe had already chosen his intended effect, precisely at the very moment of genesis. Though inspiration was a secondary aid, it was methodic discretion and the fulfilling of preconceived stages - not "an ectsatic intuition" (Poe, 1986: 481) - which really enlightened the creative culmination of the purpose. After impregnating his mind and soul with that prevailing idea, modelling it both in the province of the poem and deep within the reader's mind was just a matter of slowly turning the covert essence into explicit overtness. As a writer of the detail and the dreamy path of implied sensations buried in the word's soul, Poe, like Virginia Woolf, used language to descend into the obscure and ethereal, trying to reach the limits of art and existence. Seduced by the plural stimuli of each fragment exposed, his obsessive method of accumulation of elements stood, in fact, as a gradual constitution of his eagerness for a final reductiveness of the caught disparity, an appropriation of the self aiming to grasp the invoked trace of the sublime fluorescent aesthetic uproar.

Painter of the outside skies, eventually internalized, Poe endowed his living words, the gems in his flowing literary aspiration, with weight and idiosyncrasy, sound, melody and, above all, a lightning of colour that is, without doubt, forged personality. Words, explicit and vivid organisms in the epistemologic raid over existence as "the imagination's apprehension of itself and reality" (Davidson, 1976: 68), consequently awaken a paradigm of sensations and impressions that enrich the reading with a symbolic meaning approaching the reader to that third dimension constituted by perceptions and consciousness surpassing mere fact:

The word was a "something-other", a suggestiveness, an abstraction, and a way into the farther range of perception beyond logic and beyond the normal discourse of man. (Davidson, 1976: 69)

On his canvas, several minor brush tints -a plethora of hauntings-, the first of which we can call "primary effect", abide in perpetual contrast and metamorphosis, gradual shifts 
-a protruding and rotting inertia-, until the last overall trait of the searched emotion of solemnity, the purest one, is unveiled. Like words, characters, events and places are important precisely because they function as indirect impliers of an atmosphere, building factors meaning futile states to gather, unbalance, restless and quick passing of time, silhouettes that grow in the cavern of the obscure and lead us, the receiving mind, to interpret the whole as the final arise of the unique, the things that rust in ourselves, the everlasting emotion coming from a brief echo, the one which, for instance, reveals there is always a witnessing skull behind our beauty.

Being a methodic disciple of intrinsically poetic causality -materialized both in the logical sequence of events and, most often, in the effective temporal discrepancies of his clarifying and torturing analepses-, Poe showed his extreme ability to seduce the reader from the initial twist of interest, catching his/her titillating affinity through the first murmurs of a poem or tale and gradually controlling the suspension of the reader's scheme of circumstances to eventually bring the colours of shock. Among those partial and subsequent states as pillars of the single meaning, those chained impressions heading for the conclusive revelation, the prologuing one stands out as the tone calling for a breezing of sensation, a weak response of initiation on the reader's part. Still diffuse, not really involving or engaging, this fronting lead really connects with the reader's curiosity and inevitably influences -tempts- the reading that follows -its prism and perspective - while the text proairetically maintains the secrecy to reveal as a means to survive. ${ }^{4}$ This first stimulus remains and is exploited-developed-throughout the reading when the charge of states and chained effects arise and are assimilated. The primary effect may be founded or opposed to what follows, that is to say, as the initial data are integrated, the first traces of the literary text become resident values, hypotheses to be reinforced, modified or even, being prints of speculation, finally replaced. In that process, a drafting and redrafting of sensations, the passive receiver becomes active, is involved in the modelling of landscapes and graded presentation of pictures until the final image, either finalized (Rimmon-Kenan, 1994: 121) or oscillating -undeciable or unreadable according to poststructuralists and deconstructionists-, is reached. ${ }^{5}$

Colours, undoubtedly, became for Poe pivots for the proper exemplification of the dynamic agony, traces or stigmata to point in the interpretation of the narrative movement. Having weird fatality in mind as the unique path that abducts us and knowing every partial beat leads to the final silence of the heart -the present becoming past and this one turning into a motivation of closure-, Poe preluded impressionism and expressionism, since he adopted the pictorial causality of the former, the "dawning" or waning of colours -

${ }^{4}$ This is clearly connected with the concept of "primary effect" -the author's initial filtering- Perry refers to:

The text can direct and control the reader's comprehension and attitudes by positioning certain items before others. Perry (1979, p. 53) sums up the results of psychological tests which have shown the crucial influence of initial information on the process of perception ('primary effect'). Thus, information and attitudes presented at an early stage of the text tend to encourage the reader to interpret everything in their light (...) Texts can encourage the reader's tendency to comply with the primary effect by constantly reinforcing the initial impressions, but on the whole they induce the reader to modify or replace the original conjectures. (Rimmon-Kenan 1994: 120)

${ }^{5}$ Poe's discourses are double-sided transmissions of colour, several pictures and one, some sensations and the whole, the intended literary image, this being a natural and necessary result of the former, gathering all the preeceding elemental traces of gloom or lucidity in its essence. When we talk about the grammar of colours in Poe, we refer both to the single pictures and that final literary image, the condensation and abstraction of a whole series of states.

Odisea, $n^{0} 2,2002$ 
structured patterns presenting the effects of moving light on the subjects-, and the deliria of the latter -the semantics of the grotesque- to trascend the universal data and embellish his own subjective halls of sermon. As the impressionist artist, he became a landscapist or real focalizer but, at the same time, tried to transmit the gradual and constant yielding of a sensation to a consecutive one through the fading development of spiritual colours representing different phases in the decaying states of mind, the motion of feelings, like Debussy's artificial reflection of shifts in emotion through different and vague musical textures and moods.

Reality being his raw stimulus to be modelled by the growing trace inside, Poe painted silhouettes of our world -bleeding for us, silently letting his secrets- in an extremely visual tendency that directly exposed the impressions experienced by the artist when sharply facing and interpreting the objects of the visible, gradually slipping into oblivion. After the accumulation of details, the artist created vague shapes with blurred edges to go beyond the neat realistic details. In this, his moulds were like the slimy impressionistic vestiges forged in the hands of Manet (1833-1883) or painters such as Bautista Corot (1796-1875), Daubigny (1817-1878) and Coubert (1819-1877), a path towards symbolism and colourful subjectivism, a new perspective of the real. Furthermore, Poe garnished the landscapes of reality beyond the purest print of imitation and followed his will, his inner sense, to represent the brooding outside so as to explore the decadent waking point and distorted melting in the cauldron of the self. As Max Beckmann, Otto Dix or Georges Rouault would eventually do in the 20th century, Poe used symbolism and exaggeration -the imposition of the artists' perspective and filtering of the envisioned- so as to represent emotions opposed to the physical immediacy of emulated reality, distorting it deliberately. Symmetry was latent in his methodic madness, as a structural constant and key pillar, but, at the same time, it seemed to be absent, as utopy in the semantic core of his restless and menacing habitats, the confusing inner vortex -flaming or frozen states of desperation reflected in turbid and hectic stages such as those translated by Fritz Lang's or F.W. Murnau's cinematic language--, paradises of gloom and unbalance also shaped in the expressionistic poetry of G. Trankl, F. Werfel or G. Benn, a doorway into mind. In fact, nothing seems to be horizontally calm in his art, not even the breath of the sleeping old man in "The Tale-Tell Heart", and the dynamic essence of any claustrophobic vacuum -the ethereal surroundings in "The Pit and the Pendulum" or the damp vaults in "The Cask of Amontillado"- always follows the falling inertia of desperation into the fading abyss, the maëlstrom of a dark and marginal age. Poe's shaking and striking narrative tempo reminds us of the menacing silhouette of the hanging black cat on the burnt ruins -also an erect phallus symbolizing a seed for fertility and life- and represents the beating of lost joy, haunted by phantasmagoria, the stressing pendulum of a dehumanized industrial society, a delirium tremens also embodied by Fortunato's foolish carnival atrezzo - "a tight-fitting parti stripped dress, and his head (...) surmounted by the conical cap and bells" (Poe, 1986: 360)or the masqueraded-clan secluded from the plague in Prospero's castle -"arabesque figures (...) a multitude of dreams" (Poe, 1986: 257) -, vampire-like actants who are caught in the embryo of a bleeding-like fading colour and the embers of an extinguishing fire. 


\section{SWAN'S SONGS. IMAGES OF THE PLAGUE AND THE OBSESSIVE MELTING OF LUCIDITY. A ZIG-ZAG ON ICE. FOUR PORTRAITS AND ONE FINAL GRAVEN DESTINY}

The whole, the moving effect in Poe's lakes of sensations, is to be felt from a distance: it is deranged, and rules or acts once the lines -details deceleratedly focused- are left behind in the turbid surface of the experienced. Some of his tales and poems are constructed on the basis of darkness and remain in the desolation of the frigid silhouetted amber -the macabre absence of light growing darker, even to the darkest- as the ever-lasting enameling vision of an unavoidable catastrophe. A blatant example of this is to be found in "The Raven"; the psychology behind this composition is that of despair which delights in selftorturing, self-destruction or self-fading, deep into the marble of languid December. "Ulalume" also stands out as a poem in which cold initial solitude and massive absence, metaphorical and universal death dressed in the constants of an autumnal setting, later concretely irradiates the desolation and corruption of physical obituary, a conscious understanding of its own everlasting pain:

The skies they were ashen and sober;

The leaves they were crisped and sere-

The leaves they were withering and sere;

It was night in the lonesome October

Of my most immemorial year;

It was by the dim lake of Auber,

In the misty mid region of Weir-

It was down the dank tarn of Auber,

In the ghoul-haunted woodland of Weir. (...)

But were stopped by the door of a tomb-

By the door of a legended tomb;

And I said - 'What is written, sweet sister.

On the door of this legended tomb?'

She replied -'Ulalume -Ulalume-

' $\mathrm{T}$ is the vault of thy lost Ulalume! (Poe, 1986: 83)

Other writings, however, explicitly drive the reader and sufferer through a deeper state of inhaled desperation and tupid blackness once the balance of lucidity, previously delineated, is dethroned and the frontier of decadence trespassed. This is, in fact, a regression to the chaotic overture of overtures, the déjà vu, a threshold to that final unity and reconstruction of the self.

In the painful quest for identity -the Sublime exorcised from the terrors of the soul-, passions and purposes of the witness became for Poe the conquering discourses of the instant, the immobilisation of those futile impressions whose invisibility beyond the moment of revelation is, otherwise, lost. The voyage of the mind away from the objective frames of existence is gradually blinded by intuition and imagination since imagining is the appropriation of the nucleus contemplated in the texture of the real world and later reconstructed in the dreamlike palaces of the self. Poe's writing denotes that process of segmentation, a psychological sequencing of custom-made impressions -"detail, step by 
step, (...) by which any one of his compositions attained its ultimate point of completion" (Poe, 1986: 481) - from first assimilations of the circumstances and contextual data to ultimate reconstruction of the spirit, deconstruction by means of pictorial artifices, this being an in-between or bridge linking and cohesive state to the notorious liaison with the fading. This progression is, undoubtedly, a search for self-esteem and freedom, a journey that is prolonged through five moments, each one related to a corresponding portrayed emotion and singularly influencing effect, a gallery of lights and shadows whose lyrical movement runs from impressionistic realism towards idealism and finally idealistic realism.

Contemplation of the real $-\mathrm{a}$ perpetual conflict that epitomizes the first phase-, the representation of the objective and logical light, is a possibility, an option, not a must, for the initial picture in Poe's gallery. Both this herald, or stimulus from Nature, and the ultimate effigy of rebirth, the absolute idealization we will mention in our study -the definite pictorial response to the condensed representation of fading impressions- as a last graphic step fifth phase- at the end of the process, are external to the allegory and poetics of initiation, the alienating dream that takes place within the artist's mind, always obeying the nature and purpose of his own laws, purely fictional, purely alive and redeeming as Schiller's life in art.

Reality may appear either in the shape of a multitude or mob -as in "The Man of the Crowd"-, a microcosmos representing the order of human relations -a systematic description of society, segments and classes: lawyers, swell pick-pockets, Jewish pedlars, gamblers, businessmen and beggars-, or in the form of a resident judging assertion included at the very beginning of the literary invitation, functioning as an inductive hallmark, conclusive and persuasive in its essence, related to any human universal and preluding the flashback which welcomes the external analepsis or embedded narration that evokes "a past which precedes the starting point of the first narrative" (Rimmon-Kenan, 1994: 48), a peering into the abyss when "we stand upon the brink of the precipice" (Poe's "The Imp of the Perverse", quoted in Bloom, 1998: 26).

Fading and degradation in Poe is, in fact, a symptom revealing symbolic imagination is "poetically destroying reality and creating a substitute reality and dream" (Davidson, 1976: 103-104), each new destruction being an act of self-immolation accompanied by a "deep hollow note of the church-bell, breaking, each hour, with sullen and sudden roar" (Poe, 1986: 159), an artistic transfer of colouring and dimming from the foreground towards the background -which in Poe's opinion was latent in all paintings-, a escape from reality, unreadable and deceptive opaque captions, towards the untouched identity, finally resulting in death and ulterior birth, a shadow for an ultimate spark of light: ${ }^{6}$

\footnotetext{
${ }^{6}$ There is no purge for the romantic without pain, there is no escape from the conspiracy of the world and fate but a peering into the vortex of the sea, the assimilation of the events of the "illegitima", the remembrance of his acts of comission indirectly characterizing and chaining him to the sad end, a lonely and terrifying fall into the hell of ours, the familiar horror, like the one the protagonist in "A Descent into the Maelstrom" (1841) suffers. The painting within is a trace of exorcised past, marked by longing bidings of recovery:

Never shall I forget the sensations of awe, horror, and admiration with which I gazed about me.

The boat appeared to be hanging, as if by magic, midway down, upon the interior surface of a funnel vast in circumference, prodigious in depth, and whose perfectly smooth sides might have been mistaken for ebony, but for the bewildering rapidity with which they spun around, and for the gleaming and ghastly radiance they shot forth, as the rays of the full moon, from that circular rift amid the clouds which I have already described, streamed in a flood of golden glory along the black walls, and far away down into the inmost recesses of the abyss. (Poe, 1986: 238)

This setting of the intimate vibrant experience, the habitat of the narration and the narrated, is, consequently, the carcass of both the author and his fictional focalizers. Acting as the pictorial pocket of
} 
Two would answer all the purposes of two thousand; - one in the foregrounding as a standard, and one in the background, of a size corresponding with the artist's conception of the distance. (Poe, 1986: 435)

Once in the region of dreams - in "The Valley of Unrest" or the turgid meaningless scopes of "Dream-Land" - Poe feels continually impelled to redefine or reconstruct the semantics of the instant. The inertia to negate oneself as a sacrifice for future rewards constitutes what Vladimir Propp considered the first function of narratives, the source of dynamism materialized in the sequence of events and successive turning points heading for a conclusion, a productive detachment - very much like Victor Shklovski's 'strangement' of the contemplated object ${ }^{7}$ - which finally models a reintegration of the self:

The mind which employed itself in the discursive journey of self-exploration was never quite the total enterprise. There was another side of his mind which, as it were, remained apart from the activity of the other. While one side - that of the undeveloped adolescent with its night fears and the dreams of the lost girl-mother - was engaged in an imaginative destruction of reality chiefly in the poetry (...) the other half of the mind was attempting to make sense of reality and to put logic back together. (Davidson, 1976: 51)

Poe's deconstructive process employs three ulterior moments until reconstruction is finally attained. The first instant of decaying enhancement -second in the whole process, after contemplation and filing of the sensitive- is assimilation, usually clad in the mystics of the beyond, that which lies latent, as the poet himself acknowledges in "The Man of the Crowd":

As the night deepened, so deepened to me the interest of the scene; for (...) the general character of the crowd materially alter. (Poe, 1986: 183)

In this state, the primitive traces of reality are adapted to the artificial lucidity of the personal canvas and prism. The inner subjectivization of the external aspects, the unfolding model, results in a state of mind, allurement, we could say, specially embodied in the effigy of a supreme femininity. Reality is still implied but only distantly -in fact, the borders between what is real and unreal are not always clearly defined-, the detachment is greater and greater, the author's inner contemplation being still deeper in a displacement farther away from the immediate representation of the world, whose domains and icons have a directly waning proportion left in the canvas of the aesthetically derived dimension.

the heart and memory, the frame of the narrative -where all memories and allegories of destiny rhymebecomes almost protean, depending on the stage of involution, the moment retold, but elements within, role and functions are maintained. As a macabre Vladimir Propp-like morphology of the tale -the tale of existence- names are not important, but only roles and functions. The frame functions in Poe's regressions as a device to explore dynamics of both movement and stasis, the desperate running for freedom in a damned entity's mind, the acceleration of a flashback in a decelerated pause. Poe's narrators are descriptors of ellipses, forgotten and suddenly desinterred, in the logical sequence towards the end. It is that ellipsis that provokes the thrist, the vacuum. The narrator only feels satisfied, fully realized and purged, when colouring the abyss.

7 An envisioning and gathering of sensible elements -conventional description of them- results in a habitualized and automatic perception which, at the same time, causes the winds of the spirit to stagnate and never reach the moving effect of transcendental excitation.

Odisea, $n^{0} 2,2002$ 
Imagination and the incantatory manner rule, modelling visions that belong to an immolated past -once glimpsed- and a dreamed future in the hands of a literary prophet. ${ }^{8}$ As a corollary to this, Poe defied conventional reality, having the hubris to believe he could create life on his own:

We can, at any time, double the true beauty of an actual landscape by half closing our eyes as we look at it. The naked Senses sometimes see too little -but then always they see too much. (Poe, 1986: 498)

This force of arrogance, which leaves room for the spiritual side, allowed Poe -in the same way as Woolf's sensitive proclivity to the unseen - to explore the beyond, the boundaries of life or art as a plagiarism of the former -autobiography was an illness of his own, a virtue, a way of being loyal to himself-, a dream or fantasy-induced state that implies the complete disconnection of self and other as well as of mind and body, the alienation that can be so natural within a dream.

Permeated with a vision beyond his time, his darkness, the lost realms of agony and grime, Poe's texts imply an escape to the futile ether of the grotesque, verbalized by clogged impressions of "extravagant pictorialism" (Davidson, 1976: 78). His lines conjure up a virtual redrafted reality that unearths the hidden beat, the primitive, the desired or the feared, the dim echo of the mystical, Coleridge's secondary imagination -a haunting coven of emissions that enacted life, soul and spirit in humanized and symbolist nature- as opposed to the primary and most direct visual prompt. The writer elicits a response from himself once he provides the drastic displacement -schizophrenic and nocturnal emissions of an Adam that is cast out of reality, the visualized physical terrain- from the context of utterance and employs a context of reference that suddenly makes circumstances beyond the author himself prominent, valid and liveable:

Oh, outcast of all outcasts most abandoned! - to the earth art thou not forever dead? to its honors, to its flowers, to its golden aspirations? - and a cloud, dense, dismal, and limitless, does it not hang eternally between thy hopes and heaven? (Poe, 1986: 158)

In the construct of intimacy, a rainbow of stimulating colours, a variety of sensations accumulation of details through which the reader is supposed to visualize the gradual picture in "episodes"-, still prevails as an initial decomposed state, allegory of the cosmic chaos that finally converges on an unique colour representing the last and enduring effect. ${ }^{9}$

\footnotetext{
${ }^{8}$ The exotism of the fantastic or fabled universe created is a synthetic pastiche of invented vestiges and prints that are not purely ex nihilo, but the result of the wandering imagination over familiar elements; it is usually an amalgam of idealized icons from childhood, a private urn now filled with those actants that have been encountered throughout the years, all enshadowed by the primacy of the lover, a neat reflection of the prematurely lost mother.

${ }^{9}$ The second moment, or first trace of inventive and constructive deconstruction, comes when the author filters the input from reality -the void of materials that is to be given form and substance-, when symbolic connotation is excited. In this productive alienation, imagination, as the ordering and diffusing pattern, goes through the world of reality or selfish solicitude and conceives some comprehensible mode which only the rhetoric (Poe thought of it as music or poetry) of fancy may express or convey (Davidson, 1976: $61)$.

Furthermore, this stage in the process is a projection of the author's own seizing of reality beyond what is merely sensible -far from its restricted denotative meaning. In fact, words and images in Poe transcend
} 
Instances of this multi-mirror are the greenish and splendid variety in the Valley of the Many Colours in "Eleonora" -intensely expressive surroundings and geometrical scopes from exquisite angles of vision- or the seven motley-coloured suites in the castellated abbey in "The Mask of the Red Death", not by chance or "irregularly disposed" (Poe, 1993: 255), but following the breathing method of the narrative, manifesting the coming of death and nightfall. In fact, Prospero's site combines enlightened rooms with dark chambers, colour-coded stages in a blackening progression. This rationalization of dawning runs from blue, representing the new birth of the morning, the genesis of life and intelligence, to sombre decadent dyeing; in between the two extremes, we have purple, related to the brevity of life, justice and temperance; the wake of youth, the growing age, hope and mystical deliria brought by the green sparks; afternoon as a bridge to maturity, pride and ambition suggested by the orange colour and the three last implications of fatality in the veil of white -the mixture of all colours-, violet - nightfall, death, mourning, stagnant vitality-, black, as the absolute silk of night, nothing, destruction, and, finally, the deep and blinding red of the windows in the dwelling where Prospero's tragedy takes place.

The third state in the whole progression is clearly embedded and exemplified in the last part of the aforementioned degradation of colours -the lethally rhymed silhouette of the beloved Ligeia, Eleonora, Berenice and many other doomed femininities mirroring Virginia Clemm's suffering from tuberculosis-, a context gradually resulting in morbid oppression and darkness, death as a bridge to the apparent meaningless essence, a frontier and slippery inertia into a lost dimension -"There are moments when, even to the sober eye of Reason, the world of our sad humanity must assume the aspect of Hell" (Poe in "Marginalia", quoted in Bloom, 1998: 36). The disharmony of colours, a tone of homeliness, a taste of rain's saltwater -"it by no means follows from any thing here said, that passion, or even truth, may not be (...) profitably introduced, into a poem (...) for they may serve in elucidation, or aid the general effect, as do discords in music, by contrast" (Poe, 1986: 484) - brings about the negation of the self, which lingers on to result in the final catharsis -fourth phase- purging the personal, a context where the marbled colour embraces the bloodless diva, ceasement being a form of invisibility or a heap of ashes for the coming rebirth -"death, then, of a

the poem to live within his memories, a connoted reality shared with the reader's capacity of identification. The projection is, itself, an act of renunciation of the world that is reduced to personal conditions, submerging in the sea and changing the day's clarity for the darkness in solitude, a state that is best exemplified and conveyed in the art of poetry. As Davidson points out:

Poetry necessarily became an act of the destructive imagination. (...) Having once reshaped the real world to its imaginative needs, a process best demonstrated in the shift from jocularity to terror in "The Raven", the poem must abandon the rational intelligible world and undertake a journey toward ultimate meaning on, as it were, the "other side". (1976: 100)

But, surely, and as we will state, this representation was neither a hysteric discourse of absolute abandonment and ceasement nor a last sigh of agony leaving ultimate and meaningless traces of a search for the essence. It was a promise of return, taming and back-colonization of the dark fate, a strengthening of the subjective spirit and perspective, a revitalization of the faded colours to impose the clarity of resurrected ambition on what he left behind in the frames of reality, that despised universe of disgrace behind the instant; in a word, a reordering gained after the trance of self-discovery -sending the imagination "on a series of journeys which were means and acts of conquest of the mind over the material world" (Davidson, 1976: 54-55) -, a method the Romantic mind suffered to reveal the shaded core:

Just as Wordsworth could talk about that which we half-perceive and half-create and Coleridge could argue that the outside world only becomes alive through the shaping spirit of the poet's imagination, so Poe felt that the prime impulse of the artist must be towards restoring an original unity to the chaos which seems to surround the poetic spirit. (Whitley: viii-ix)

Odisea, $\mathrm{n}^{\mathrm{o}} 2,2002$ 
beautiful woman is, unquestionably, the most poetical topic in the world (...) and equally is it beyond doubt that the lips best suited for such topic are those of a bereaved lover" (Poe, 1986: 486).

Images of cemeteries and crypts stand out, immersed in white, red and black backgrounds. The mixture of these three codes that melts feelings into the deep red of blood -white as a vestige of purge but also as paleness, deprivation of the vital fluid; red as turgent passion of the dead maternal bride, a hideous phantasm sired by the insane narrator, but also bleeding as the setting sun; black as the absorbing vampire-like colour- is usually employed to represent the new enshrouded world -anaphorically linked to the gradual languid detaching innuendo, the traumatic dissolution of heterogeneity-, a state calling for a compensation from beyond, a turning point, an awakening - cataphoric reference to the effect bringing the code of new existence, the homogeneous texture of the self. As carved in "The Sleeper":

Looking like Lethe, see! the lake

A conscious slumber seems to take

And would not, for the world, awake.

All beauty sleeps! (Poe, 1986: 73)

A new form of definition and description arises when the reader acknowledges and accepts Poe's linguistic and thematic codes by reference to deviant models of the author's coherence (Rimmon-Kenan, 1994: 128): a marriage to the lying maiden -mixture of white stained with blood, "Strange is thy pallor! strange thy dress!/ Strange, above all, thy length of tress,/ And this all solemn silentness!" (Poe, 1986: 74) -, a Sleeping Beauty that is now focalized at the centre of the stylized vision as the most prominent object of desire. This unique effect, "the Irene-figure (...) freshly adorned for burial" (Davidson, 1976: 120), vigour of fascination now -in the fifth representation, fourth state of deconstruction- tempts the beloved and manifests herself in a form of beauty which does not wither, which transcends death like a spell of vitality remaining in the eyes of the deceased to murmur the last colouring of reconstruction. ${ }^{10}$

An overlook at the aforementioned process leads us to the explicit function of those five states depicted in the progressive creative method, from realism to extreme idealism, each of them playing a singular role:

a) Response to sensitive stimuli. Stability to be distorted.

b) Strangement, which implies an attempt at the definition of the new state, only to be born this way.

c) Association and comparison. Through images of the grotesque and suffering, visions are likely to create nuances or innovating meanings.

d) Final allegory prompting a metaphorical definition of the primitive self. Gradual devoicing of the trance.

e) Tempting and definite embellishment of the metaphor: Resurrection.

\footnotetext{
${ }^{10}$ Poe became a lustrous and sensual landscapist of death and portrayer of the grimace of desperation, a dreamer within the ruinous in a time when "death became not an event or an action nor a condition of total non-being but a series of seductive postures" (Davidson, 1976: 113). His Gothic abbeys, his decadent sites are homages to the Classical degenerated, spots of a past glory and radiance that still cast a spell on the sensitive mind:
}

Rome, the crepuscular half-light which bathed the silent monoliths fallen in decay, and the "philosophy" of ruin and death as the major subject for painters and writers all fuse in a twilight sensibility that affected more artists than only Edgar Poe. (Davidson 1976: 116)

Odisea, $\mathrm{n}^{\mathrm{o}} 2,2002$ 
All these functions can, in fact, be related to a process of initiation in which, after a stimulus of out-contemplation, after a period of artificial happiness in the bosom of company, the subject isolates him/herself ${ }^{11}$ from collectivity, looks for the ideal of individuality -inner contemplation- and goes through a set of stages or drafts of existence to gain the seed of mysanthropy so as to be born again in the duet of the macabre and everlasting passion offered by the dead bride -motherly bosom-, productive derivation of his self-exposition and cleansing exorcism. In the needed isolation, in that dynamic statism of echoed and pictured life, the sense of prelude is almost struendous and choking. Therefore, an intense beating of the will on the other side of the literary mirror is the unique shroud that lasts forever covering the soul of the sufferer. Only dreaming is possible, a dream that is a conscious death, a dark sigh after having been buried alive, in an airless sepulchrum, in the lone turret of a chateau, like Madeleine Usher's copper-lined vault deep underneath the house of shadows ${ }^{12}$, the bridal chamber. As Davidson asserts:

$[\mathrm{T}]$ he room was not a room but the place of the dead woman, and the coffin easily became the bridal bed. (120)

\section{THE RAINBOW OF DOGMATIC DISEASE: COLOURS OF THE TRANSCENDENTAL FAITH AND THE WEIRD RESPONSE. RITUAL INCANTATIONS FOR THE FOREVER WHITE}

As a donor of carnival and harlequin's masks and an antagonist of the dormant soul in apathy, Poe tried to catch the transcendental, concretizing the sensuous purity of sadness

${ }^{11}$ Loneliness is the absolute clue, the privileged invitation for self-discovery and the ulterior encounter with contextualization. In "Alone" -not included in any of the writer's published volumes-, Poe describes his sense of blissful isolation and apartness in terms of his unique sensibility:

From childhood's I have not been

As others were $-\mathrm{I}$ have not seen

As others saw $-\mathrm{I}$ could not bring

My passions from a common spring-

From the sane source I have not taken

My sorrow -I could not awaken

My heart to joy at the same tone-

And all I lov'd -I lov'd alone. (Quoted in Davidson, 1976: 129)

That exclusive trait projected an aura of supremacy that in "Dreams" becomes a longing for eternal abiding in the disguised trance, sad but even more precious and meaningful than the cold reality/ of waking life. This motif is echoed in "A Dream Within a Dream", in which the aparted figure of the poet stands, as an obsessive ether reaper, by the ever-changing sea, patiently watching the golden grains of sand -his dreams- slipping relentlessly through his fingers into the water of the infinite.

12 Poe's extreme alienation, his search for the inner light and the ultimate reason for his self, his everlasting obsession with the quenching of his thrist with the knowledge of the individual and the values of behaviour, walled him up in a volcano of emotions under whose flaming coalescence of causes and effects, he enjoyed the privilege of being the victim, approaching the last hour in the darkest cellar, feeling at home. More than an American or a citizen of the world, he was a patriot of his own neverneverland. As Lewis Leary puts it:

I have already mentioned that Poe is revered as a great American writer, but that estimate raises obvious problems, for how far can Poe be seen as American? His stories are usually set in some imaginary or at least unnamed land. Where is the House of Usher? Perhaps it were best to say that most of his tales and poems occur in a place he locates (in 'Dream-Land') 'Out of SPACE -out of TIME'. (quoted in Leary, 1961: vi)

Odisea, $\mathrm{n}^{\mathrm{0}} 2,2002$ 
-the only thing that lasts forever, the scar that never heals-, so as to pour it over the eyes of the reader. Chanter of unbalance, he chose to portray the extreme state of happiness and the sudden siege of a faultless desolation, both in the glimpse of a sigh that murmurs right at the core of nature and the most profund abyss of the self. The first act of the so-called "tragedy of man" takes place latently in the aforementioned fictionalized and reshaped reality, the one we will call the portrait of unscriptured waters. Scenes of idyll are chained together in a flash of seeming permanent calmness, the breezing whisper, the splinter before the storm-, a realm of alienation, of strangement, where creeds of light -like the metaphors of opium- rule an empire of pleasure, a paradise of joined hands:

[T]hese spots, not less than the whole surface of the valley, from the river to the mountains that girdled it in, were carpeted all by a soft green grass, thick, short, perfectly even, and vanill-perfumed, but so besprinkled throughout with the yellow buttercup, the white daisy, the purple violet, and the ruby-red asphodel, that its exceeding beauty spoke to our hearts, in loud tones, of the love and of the glory of God. And, here and there, in groves about this grass, like wildernesses of dreams, sprang up fantastic trees, whose tall slender stems stood not upright, but slanted gracefully towards the light that peered at noon-day into the centre of the valley (...) Strange brilliant flowers, star-shaped, burst out upon the trees where no flowers had been known before. The tints of the green carpeted deepened; and when, one by one, the white daisies shrank away, there sprang up, in place of them, ten by ten the ruby-red asphodel. And life arose in our paths; for the tall flamingo, hitherto unseen, with all gay glowing birds, flaunted his scarlet plumage before us. The golden and silver fish haunted the river (...) within a magic prison-home of grandeur and of glory. (Poe, 1986: 244-5)

But initial and innately damned glory is not always a greenish conjuring for the poet in the opening of curtains or first revelations of colours and, in the same way, death's coming, the grotesque to burst, may not be so opaquely hidden either. In some of the preluding prints materializing Poe's fictional flashbacks, we already find a gloomy echo of the intradiegetic present situation from which the narrator, heading for the announced end, intercalates the artistic remembrance to be widened. Several embers of horror and derangement are murmured by the sufferer when quoting his past, when revitalizing it through the first portraits of suspension. It is as if the narrator, on decelerating the initial moments of confession as a desire to delay the doom, were conscious of the protruding and poisonous breath of a menace "while from a proud tower in the town/ Death looks gigantically down" (Poe, 1986: 71).

One of the gloomiest materializations of this latent fear in the bosom of the early beauty abiding in the first state of deconstruction, is, apart from the explict proleptic stigma in titles flashfowarding the disaster - "The Black Cat", "The Pit and the Pendulum", "The Raven", "The Bells", "The Fall of the House of Usher" or "The Masque of the Red Death"... - , the thematized approaching vision that the dynamic focalizer has of the eerie mansion of Usher. ${ }^{13}$ In this piece of centripetal insanity, the sublime is presented as a nostalgic and

\footnotetext{
${ }^{13}$ The prophesized disgrace is also latent in some richly adorned portraits of false calmness. Take, for example, the mystical and mythological splendour of Lady Rowena's bridal chamber. Each portion of its exotic decoration and architecture, represented by the exquisite cloth and golden candelabra -funeral candles, no doubt-, seems to hide, in the "ghastly lustre" of menacing silhouettes and the shaded space
} 
gothic-like threatening macabre splendour. Atmospheric and figurative language brings the depiction of the dark pit, the nightfall -in clear similarity with the emotive focalization of the narrator (pathetic fallacy)-, while the analogous spirit of the witness of horror impregnates the tableau with the first moving or "insufferable" (Poe, 1986: 138) feeling of pleasure, a sentiment "with which the mind usually receives even the sternest natural images of the desolate or terrible" (Poe, 1986: 138):

During the whole of dull, dark, and soundless day in the autumn of the year when the clouds hung oppressively low in the heavens, I had been passing alone, on horseback, through a singularly dreary tract of country, and at length found myself, as the shades of the evening drew on, within view of the melancholy House of Usher.(...) I looked upon the scene before me -upon the mere house, and the simple landscape features of the domain -upon the bleak walls -upon the vacant eye-like windows - upon a few rank sedges - and upon a few white trunks of decayed trees -with an utter depression of soul which I can compare to no earthly sensation more properly than to the after-dream of the reveller upon opium -the bitter lapse into everyday -the hideous dropping off of the veil. There was an iciness, a sinking, a sickening of the heart -an unredeemed dreariness of thought which no goading of the imagination could torture into aught of the sublime. (Poe, 1986: 138)

The picture is more than just a cold and twisted touch of the invisible supremacy and agitating vapor enshrined in ambivalent shiverings, more than just the enshrouded mould of a depressive soul suddenly matching the desolate appearance of the looming mansion not found by chance, of course, this is also more than a pause, more than a static delirium, since the threshold of the weird house, that facing the agent of vision, immediately comes to function within him, after possessing the viewer's mind and being possessed by him,

within the walls, the lamenting fate - oppressive and unavoidable like the overwhelming presence of the "immense" "sole window" and the "unproportionably" "gigantic" "lofty walls" - of a place that is to become the lady's mausoleum. An "ebony bed" or "sarcophagous" under the "vaulted" ceiling is ready for the coming of nemesis. Note the expressions of doom in italics (ours):

The room lay in a high turret of the castellated abbey, was pentagonal in shape, and of capacious size. Occupying the whole southern face of the pentagon was the sole window -an immense sheet of unbroken glass from Venice -a single pane, and tinted of a leaden hue, so that the rays of either the sun or moon, passing through it, fell with a ghastly lustre on the objects within. (...) The ceiling, of gloomy-looking oak, was excessively lofty, vaulted, and elaborately fretted with the wildest and most grotesque specimens of a semi-Gothic, semi-Druidical device. From out the most central recess of this melancholy vaulting, depended, by a single chain of gold with long links, a huge censer of the same metal, Saracenic in pattern, and with many perforations so contrived that there writhed in and out of them, as if endued with a serpent vitality, a continual succession of parti-colored fires. Some few ottomans and golden candelabra, of Eastern figure, were in various stations about -and there was the couch, too -bridal couch- of an Indian model, and low, and sculptured of solid ebony, with a pall-like canopy above. In each of the angles of the chamber stood on end a gigantic sarcophagus of black granite, from the tombs of the kings over against Luxor, with their aged lids full of immemorial sculpture. But in the draping of the apartment lay, alas! the chief phantasy of all. The lofty walls, gigantic in height - even unproportionably so- were hung from summit to foot, in vast folds, with a heavy and massive-looking tapestry -tapestry of a material which was found alike as a carpet on the floor, as a covering for the ottomans and the ebony bed, as a canopy for the bed, and as the gorgeous volutes of the curtains which partially shaded the window. The material was the richest cloth of gold. (Poe, 1986: 118-20)

Odisea, $\mathrm{n}^{\circ} 2,2002$ 
inviting him into the inner shadows, into that gallery of nightmares which constitutes the chain of events or turning points in the blackened anticipation. That "sickening of the heart" preludes the horror, the perverse inhabiting behind those walls. Furthermore, not to be obviated, in the zigzaging crack on the façade -the implicit impure and imperfect scar blighting the beautiful serenity - the line of life coming to an end -in the tarn of grotesque reflections-, the unique and last meaning of the final picture is veiled. This fissure is, like the spectral prominence of the insistent heart-beat in "The Tale-Tell Heart", the physical embodiment and obsessively vivid externalization of the subliminal damnation awaiting, what is there -overtness- and not there -covertness-, what you can see now and then you do not, more things than are dreamt of.

"Ligeia" presents another of those panoramic initial visions in the hierarchy of sequenced effects prompting the announced disaster within the first stage of tranquility. In this case, an unknown picture of overwhelming beauty, an ethereal limitless soul of the sublime with a tear of strangeness in her proportion of magnitudeness -another zig-zaging mark of the oracle, another rainbow of colours-, unveils the trance of blackness to which every sense will eagerly and avidly yield in an end of abstinence -"Melancholy is thus the most legitimate of all the poetical tones" (Poe, 1986: 484). The beginning of the trance in "Ligeia" shows the wake of the effect to be ultimately found and immediately forces the reader into the hypodiegetic colours of the embedded narrative. Confusion reigns but the purpose is definitely consistent: telling about the scar and justifying its languid and sinister echoes:

Or perhaps I cannot now bring these points to mind, because in truth, the character of my beloved, her are learning, her singular yet placid cast of beauty, and the thrilling and enthralling eloquence of her low musical language, made their way into my heart by paces so steadily and stealthily progressive that they have been unnoticed and unknown. (...) The 'strangeness,' however, which I found in the eyes, was of a nature distinct from the formation, or the color, or the brilliancy of the features, and must, after all, be referred to the expression. Ah, word of no meaning! behind whose vast latitude of mere sound we intrench our ignorance of so much of the spiritual. The expression of the eyes of Ligeia! How for long hours have I pondered upon it! (Poe, 1986: 110-12)

Carpeted by soft green and red ruby, brilliant in color or with the dew of threatening shades, the spell of the ephemeron -the proleptic vignette of the fall- is cast at the core of these preluding visions, more or less explicitly, becoming the shining of grace soon to be spoiled in Poe's hands, in the traumatic spasms of his distorting and erasing brush. His inertia of description towards the diffused, the fading of colours to come, follows the movement of the "River of Silence" in "Eleonora", that which escapes the encircled domain of purity and stillness to enter darkness, "a shadowy gorge, among hills still dimmer" (Poe, 1986: 244). The range of bright and effervescent streams, reminder of explicit presences, finally loses hilarity and reaches -after the iconicity and thematization of some fading colours in a linear hierearchy of effects, each one closer to the tight close-up level of absence- the lack of colours -black- or the homogeneous and unique mixture or chemical combination (Poe, 1986: 497) of them -white- we have assigned to the last but one state of deconstruction -"Even out of deformities it [imagination] fabricates that Beauty which is at once its sole object and its inevitable test" (Poe, 1986: 497). The radiance of the picture changes and the location portrayed is rather a decaying urn, the "Valley of Unrest": 
Ah, by no wind those clouds are driven

That rustle through the unquiet Heaven

Uneasily, from morn till even,

Over the violets there that lie

In myriad types of the human eye-

Over the lilies three that wave

And weep above a nameless grave!

They wave: -from out their fragrant tops

Eternal dews come down in drops.

They weep: -from off their delicate stems

Perennial tears descend in gems. (Poe, 1986: 76)

During the horrendous weeping, the sun is dethroned by the magic moon. Day fades in the whispering bandages of night, bringing either the frozen representation of the despairing colours of chaos -a vacuum-like withering white, the extinguishing fire of a "sickly yellow" sun, like "dim, silver-like rim" with a "dull and sullen glow" (Poe, 1986: 102), the gray hair of the zombie-like crew in the sinking ship in "Manuscript Found in a Bottle" or the vulture-like "pale blue eye" (Poe, 1986: 277) in "The Tell-Tale Heart", as well as the thick gloom of perdition in the unfathomable sea, the "Mare Tenebrarum, the liquid ebony"14 (Poe, 1986: 239) in the whirl of the Maëlstrom; other examples being Lady Rowena's "ebony bed" in "Ligeia", the blackened funeral atmosphere invading Prospero's suite-, or the last fierceful sigh of "burning" passionate horror exemplified in the bloody moon over the House of Usher, undoubtedly related to the scarlet marks on Madeleine's "white robes" (Poe, 1986: 157) -like Lucy's impurely stained nightgown in the first encounter of voyeuristic pleasure and damnation with Dracula in Stoker's novel-, Berenice's assassin's stigmatized hands, the scarlet panes with "a deep blood color" (Poe, 1986: 255) in Prospero's death chamber, as well as the cat's "red extended mouth and solitary eye of fire" (Poe, 1986: 329) in "The Black Cat". ${ }^{15}$ White, red and black, once again, as components of dense blood-red.

It is, in all cases, the metamorphosis caused by the approaching beating of the pendulum at the mouth of the pit and the abyss, the torturing definite disclosure and result occurring between the second and the third state of deconstruction, "the last sad change which must befall Humanity" (Poe, 1986: 246), the obscure rigor mortis that replaces the perfect lucidity of joy, of birth, presenting the new draft elaborated by "the finger of death" (Poe, 1986: 246) upon the bosom of the first annunciation of innocence, a highlighted transfer from fused emotions to emerald-like tolling melting, from vitalist and warm -even seething-colours to the freezing cramps, like the imminent chaos and storm in "Manuscript

\footnotetext{
${ }^{14}$ This is a similar testament of the darkness and decay that comes with the Red Death, the same ebony touch that tinges and shadows the clock in the palace when it stops "beating" and torches expire.

${ }^{15}$ And in that colour of putrid coldness or acid-like red of desperation, Poe's masterful tinge of masochism remains fresh eternally. The poet decelerates the tearing perception to widely see and let see, to artistically suffer, as the viewer in "A Descent to Maëlstrom":

I must have been delirious -for even I sought amusement in speculating upon the relative velocities of their several descents toward the foam below.(...)

It was not a new terror that thus affected me, but the dawn of a more exciting hope. This hope
} 
Found in a Bottle", the preluded descent into hell, soon before destruction, a tantalizing "despair which delights in self-torture" (Poe, 1986: 487):

My notice was so on afterwards attracted by the dusky-red appearance of the moon, and the peculiar character of the sea. The latter was undergoing a rapid change, and the water seemed more than usually transparent. (...) The air now became intolerably hot, and was loaded with spiral exhalations similar to those arising from heated iron. As night came on, every breath of wind died away, and a more entire calm it is impossible to conceive. (Poe, 1986: 100)

The desecration of the self takes several beatings and steps to consecrate, it being a methodic falling into the eye of madness -symmetrical to the constitution of the alreadygone glory and pompous clarity of images. Agony and the fading of colours must last, even though, remembered, it is just the brief expiring sigh of that which, horribly, "had been made perfect in loveliness only to die" (Poe, 1986: 246):

The star-shaped flowers shrank into the stems of the trees, and appeared no more. The tints of the green carpeted faded; and, one by one, the ruby-red asphodels withered away; and there sprang up, in place of them, ten by ten, dark eye-like violets that writhed uneasily and were ever encumbered with dew. And Life departed from our paths; for the tall flamingo flauted no longer his scarlet plumage before us, but flew sadly from the vale into the hills, with all the gay glowing birds that had arrived in his company. And the golden and silver fish swam down through the gorge at the lower end of our domain and bedecked the sweet river never again. (Poe, 1986: 247)

The purpose of unity, the pursuit of the unique effect -obsessively searched by the artist, "[A]s the labor drew nearer to its conclusion, there were admitted none into the turret; for the painter had grown wild with the ardor of his work, and turned his eyes from the canvas rarely" (Poe, 1986: 252) - is finally achieved in the perfect isolation of the neurotic mind -when definitely passing the needle through the frontier between the real dimension and the myriad of the therapeutic grotesque beyond- while the final strike of a startling image is modelled, resulting in the most admirable portrait and declining visage, that in which the universal incantation of the pallet becomes a concrete vacuum of abyss -fourth state of deconstruction:

The arms, the bosom and even the ends of the radiant hair, melted imperceptibly into the vague yet deep shadow which formed the back-ground of the whole. (Poe, 1986: 251)

The singular and finally mastered appeal of senses is, consequently, manifested in the arising of that last colour of disgrace and collapse -sometimes, as in "Morella", insanely impelled by the narrator himself, once he is conscious of the inevitable legacy and dyeing of misfortune, the colour of frailty- standing for the constitution of the ultimate spasm. All the stars become one focalized emotion, like the "oneness involved in the stories" (Whitley, 1976: ix), like the communion of Roderick, Madeleine and the House of Usher, all expiring, at the same moment, turning into a unique reflection on the tarn, or the vampirized wife's life - 
her several features to portray- flickering into the languid smoothness of death -spiraling downward- in "The Oval Portrait", all resembling what Roland Barthes calls sublime "punctum" in a photograph -"that accident which pricks me (but also bruises me, is poignant to me)" (Barthes, 1978: 27).

Only a voice of macabre pride, a half cry of desperation, remains. The narrator leaves the simulachrum, the niche of remembrances or forced anticipations, with no hope to survive the present once he is "lost in reveries" (Poe, 1986: 252). However, a vast sigh of emotion is left within his phantasmagoria: the satisfaction of having managed to draw and capture the fourth picture -a tint of virtue and skill on the artist's part-, having presented the true secret of its effect, the main rival that escapes our understanding, death, the solemn effigy of the architecture of horror that will stay forever by our sides in the chiaroscuro, the deprivation of everything as the treasure and legacy of nothingness in a damned soul, exhumed by the last echoing and epitomizing line in each stanza in "The Raven":

Only this and nothing more (...)

Nameless here for evermore. (...)

This is and nothing more. (...)

Darkness there and nothing more.(...)

Merely this and nothing more (...)

' $\mathrm{T}$ is the wind and nothing more! (...)

Perched, and sat, and nothing more. (...)

Quoth the Raven 'Nevermore' (...)

With such name as 'Nevermore' (...)

Then the bird said 'Nevermore' (...)

Of 'Never- nevermore' (...)

Meant in croaking 'Nevermore.' (...)

She shall press, ah, nevermore! (...)

Quoth the Raven 'Nevermore' (...)

Quoth the Raven 'Nevermore' (...)

Quoth the Raven 'Nevermore' (...)

Quoth the Raven 'Nevermore' (...)

Shall be lifted -nevermore! (Poe, 1986: 77-80)

That concluding and frozen stability of the picture -"tantalizing opacity of the signs and semiotic of death and dissolution" (Kennedy, 1998: 182) - , a portrait for the ever coming in which neither time -now "a vast amorphous idea in which the objects from the past assumed a timeless reality" (Davidson, 1976: 117-118) - nor space have meaning, becomes the vital ruin, the catacomb for rebirth, reincarnated in the image of Irene, her long hair, her shroud-like gown, her immaculate virginity, both the scaring and lovely lure and the psychodrama of life-into-death, ethereal beauty -"portraits in the manner of sully. The tone of each picture is warm, but dark. There are no 'brilliant effects'. Repose speaks in all" (Poe, 1986: 419). The immobile eyes and the appearance or weaving of that last tint are embodied in the adorned and stylized tombs, palace-like shrines of marble, that yield forgotten to the winds in "The City in the Sea", the realm of enthroned Death - "(...) lying alone/Far down within the dim West,/Where the good and the bad and the worst and the best/have gone to their eternal rest" (Poe, 1986: 71) -, a graveland where everything captures the feelings of a colour that does "resemble nothing that is ours" (Poe, 1986: 71). The canvas is then

Odisea, $n^{0} 2,2002$ 
impregnated with the trascendental opulence of the sleepers in death-like meditation, under "no rays from the holy heaven (...) On the long night-time" (Poe, 1986: 71).

Yet, Poe showed the ideal process towards the enthronement of the sublime is not even yet completed with this fourth portrait, the inactivity of death, as Morella's promise to transcend rigor mortis or Ligeia's quotation of Joseph Glanvil's words -"Man doth yield him to the angels, nor unto death utterly, save through the weakness of his feeble will" (Poe, 1986: 117-118) -, both in their agonizing trance, do make explicit. The no-beyond-darkness is obviously not the definite colour to fix the ultimate effect. So much pain and distorted passionate absence of traits may well rather derive in the final compensation or metaphorical construct surpassing torture for the sake of it. From the open graves relieving the trauma of being buried alive in the collapsing chaos- the concepts of immortality will rise as the red waves of the void reunite the horizons in the coven of unlife. Instead of choosing to fossilizely accept the vision of death or escaping and finally resign to the new coming of the worst ${ }^{16}$, the silky bride and everdisappearing mother -prematurely laid to rest- is mourned in a new transcendental invitation, as if white would soon regain vitality and black were to beget the vortex of tied lights. Death, like the milky cataract Gordon Pym plunges himself into, is a gruesome and terrifying vision the narrator cannot resist for long, as he actually admits when disguising himself as a chalk-and-blood-stainedface-swollen corpse that does not encounter putrefaction.

And so, from the paleness of disgrace and the banquet of a darkness born in loneliness, Poe's lost Lenore comes wandering in balletic grace to conquer a new realm of truth in her blasphemous return, the projected metaphor -expressed by a close zooming picture of the essence- of a final shelter and reintegration -"The life upon her [Lenore's] yellow hair but

arouse partly from memory partly from present observation. (Poe, 1986: 239)

${ }^{16}$ In some cases, Poe was cruelly detailed in the manifestation of the worst. Even in the absoluteness of death, a sigh of anticipated hope may also grow beyond desolation, into complete reconstruction of the self, only to fade once again and carve the sombre sensations back to the torn peace. This usually has the form of a frigid and worthless rapid attempt of recovery and escape - unloyalty that is eventually punished-, the finding of an artificial idyll portrayed -But the void within my heart refused, even, thus, to be filled" (Poe, 1986: 248) -, a new source of love of limited essence that is soon condemned, once death elongates to stay. Two fading processes are employed, as two successions, the first being a poignant scar and the second a sure ceasement. This repetitive frequency of disgraceful events reinforces fatality as an unavoidable taste of nemesis. We have a morbid example of this torturing recurrence in "Ligeia" and "Eleonora", in which the narrator's futile awakening to a new reality after the sorrow of a "weary and aimless wandering" (Poe, 1986: 118) implies a false revival of colours, hiding the final collapse, the aforementioned definite fading to black:

I found myself within a strange city, where all things might have servered to blot from recollection the sweet dreams I had dreamed so long in the Valley of the Many-Colored Grass. The pomps and pageantries of a stately court, and the mad clangor of arms, and the radiant loveliness of woman, bewildered and intoxicated my brain. (...) [T] he world grew dark before mine eyes. (Poe, 1986: 248)

Escaping the habitat of desolation, consequently, abandoning the setting of disgrace and the chaotic state -surely as a closure of the past-, may seem to guarantee freedom and recovery for the sufferer, though it is not like that. If the mundane and urbane valley, for example, is a place of final damnation and vice for the narrator in "Eleonora", the abbey where the sufferer flees to in "Ligeia", the limits where the marriage to Lady Rowena and Ligeia's rebirth take place, deepen into the dark tone, bringing no trace of light, since it is, in essence and conceptual abandonment, not far from that "dim and decaying city by the Rhine" symbolizing both Ligeia's conception and end:

After a few months, therefore, of weary and aimless wandering, I purchased, and put in some repair, an abbey, which I shall not name, in one of the wildest and least frequented portions of fair England. The gloomy and dreary grandeus of the building, the almost savage aspect of the domain, the many melancholy and time-honored memories connected with both, had much in unison with the remote and unsocial region of the country. (Poe, 1986: 118)

Odisea, $\mathrm{n}^{\mathrm{o}} 2, \quad 2002$ 
not within her eyes-/The life still there, upon her hair -the death upon her eyes" (Poe, 1986: 75), like the "innapropriate splendour" (Poe, 1986: 146) in Roderick Usher's picture of painted ideas of awe, "an excited and highly distempered ideality of sulphureous lustre" (Poe. 1986: 145).

A fifth picture, then? A new inflection and rise of the entombed shadows? An aftermath? An afterglow? A final exulting brushstroke? It is definitely so. Death is not indelible. Echoes of the idolized beloved's muttered words wave the veil -"I longed for the love which had before filled it to overflowing. At length the valley pained me through its memories of Eleonora, and I left it forever for the vanities and the turbulent triumphs of the world" (Poe, 1986: 248) - the opiated narrator chooses to cover his eyes and within that trance he prefers to abide -the "contemplated fall into writing entails the literal death of the writer while promising his symbolic survival as an inscribed presence" (Kennedy, 1998: 192). This sacrifice at the edge of insanity, joining hands with the dead, rewards him in the end. The thirst for ideal beauty, that which, as the poet wrote in "The Poetic Principle", is "unquenchable, belongs to the immortality of Man and whose elements (...) appertain to eternity alone" (quoted in Walker, 1993: 125), is satiated while the lips of pain are forever sealed in the bosom of reanimated death ${ }^{17}$, within the flow of those darkened waters invoked in "For Annie" -"I have drank [sic] of a water/That quenches all thirst: -/Of water that flows,/With a lullaby sound,/From a spring but a very few/Feet under ground-/From a cavern not very far/Down under ground" (Poe, 1986: 85).

To sum up, Poe's epistemology of colours represents our metaphysical anxiety of bordering upon ceasement and trascend it. Feeding upon death, the poet being released from pain, resurrection may take place, death becoming "Life itself!" (Poe, 1993: 253) in the fifth representation, the picture of reconstruction -reanimation conceived in the God-like artist's mysanthropic and mental collapse-, the one in which utopy feeds the undead and the lackness of the soul turns a bright -once again- desire. Death becomes a parenthetical productive state for the Adam-like narrator, a result from his release from the false eden of reality -dayfright left in fear- that brings forth a disclosure of vitality via the trance of melancholy or accusing voices of guilt for any diffuse crime committed in the prime rejected paradise, a period of victimized languor, Adam's wandering when dressed in Morella's shroud. As Kennedy puts it, the canvas "extracts life to perpetuate it; it emulates death to deny it" (1998: 192). This beats in "For Annie":

And I lie so composedly,

Now, in my bed,

(knowing her love)

That you fancy me dead (...)

But my heart it is brighter

Than all of the many

Stars of the sky,

For it sparkles with Annie-

It glows with the light

Of the love of my Annie-

\footnotetext{
${ }^{17}$ Davidson defines the prosperous brilliance beyond the opaque dust of time: "Death was, archeologically speaking, almost denied; for the monuments and tombs of men could come alive and speak to men just as did the unmoving shapes in Poe's poem, 'The City in the Sea'. (...) In fact, art would be man's triumph over time and death and decay: the uncovered statue, the lost poem" (1976: 117-118).
}

Odisea, $n^{\circ} 2,2002$ 
With the thought of the light

Of the eyes of my Annie. (Poe, 1986: 86)

Obsessively oriented towards the possible reintegration of the self, besieging the last remnants of the objective reality, heading for the desired noumenon, the poet finally achieves the vision of the vision, the trascendental anchorage of the individual and the purest and most solid light at the end of the path within, the tasteful furnishing and adjustment of colours -"the proper quantum, as well as the proper adjustment, depending upon the character of the general effect" (Poe, 1986: 415).

On finally kissing the pale horse, the "tranquil but magical radiance" (Poe, 1986: 420) and aureole -not detestable "unquiet lights", discordant and displeasing effects (Poe, 1986: 416) -, the walk within towards the nothing-everything, becomes the founding principle of a rebirth, a glare and glitter that is not perverted taste but "a mild, or what artists term cool light, with its consequent warm shadows" (Poe, 1986: 416). After having depicted -and thought- the unknown, following Kant's delirium as a basis to see and feel the essence in the absolute dark, in the vacuum -this being the unique valid portrait in the vastness exposed to one's perception-, the definite complexity of metaphors and flowing waters within materializes. Embellished by the exhausting but revitalizing power of reflection and reaffirmation, the summoning of senses turns an elegy of fairy vigilant overtures through the intensely shining looking glass, the intended contemplation of the supreme, after the opulence of sensibility -that dying noticeable which becomes covertness- fades away and dreams, the overtness in the newly created dimension, awake not only the dead -"My love, she sleeps! Oh, may her sleep,/ As it is lasting, so be deep!" (74) - but also those sufferers that mourn -with no thrilling of groaning threats, in sacrificial expectancy and invocation under the crepuscular feeble waves of lucidity- the porcelain bride -not Gordon Pym's disquieting depiction of the dead sailor, obviously - to consummate the ultimate marriage with the bleached pallor of the virginal revenant. This undiscovered, missing, unconquerable and surpassing self is not artistically drawn until Poe's skilful hand drafts the final white of the languid phantasmagoria, the dehabitualized fraternity and love of the dead, the defamiliarized corroded beauty - maybe a final contrast between the pale extinction or dismal torpor, Ligeia's "ghastly cerements" (1986: 126) or the fetish white of Berenice's teeth, and the return of the adored dark repressed, also obscurely and fully sparkling and deliciously alienating, "huge masses of long and dishevelled hair (...) blacker than the raven wings of the midnight! (...) And the black, and the wild eyes -of my lost loveof the lady- of the LADY LIGEIA" (1986: 126), our contemplated Adam's Eve. Smoothly running the climax follows, once the transient elevation of the soul is reencountered:

Here then the poem may be said to have its beginning -at the end, where all works of art should begin- for it was here, at this point of my preconsiderations, that I first put pen to paper in the composition of the stanza. (Poe, 1986: 487)

Within the abyss, the dark cognition derives in the prolonged aesthetic, febrile and revitalizing transparency of devious spiritual nourishing art, the art which is never to be forgotten, the one which, epitomizing self-preservation, exists so that "one may recover the sensation of life" (Shklovsky, 1965: 12) in the encasement of seductive cerements as the poet finally manages to tame and marry the Sublime, a refuge that hails his entrance, an own interpretation of the self-made word, soul that trascends the corruptibility of the flesh, the 
colour of bare hearts, since "only writing seems to provide a source of coherency" (Kennedy, 1998: 169). A colonisation of eternity is elitely jeopardized and disclosed in the oneiric projection of a death cyclically rehearsed, unfolded and finally banished.

\section{REFERENCES}

Barthes, R. 1978. Camera Lucida: Reflections on Photography. Trans. R. Howard. New York: Hill and Wang.

Bloom, C., ed. 1998. Gothic Horror. London: MacMillan.

Broncano, M. 1996. Introducción. El Gato Negro y Otros Cuentos de Horror, de Edgar Allan Poe. Barcelona: Vicens Vives. vi-xliv.

Davidson, E. H. 1976 (1957). Poe: A Critical Study. Cambridge, Massachusetts and London: The Belknap Press of Harvard University Press.

Galloway, D. 1986. Introduction. The Fall of the House of Usher and Other Writings, by Edgar Allan Poe. London: Penguin. 9-46.

Hamon, P. 1982. "What is description?" French Literary Theory Today: A Reader. Ed. T. Todorov. Trans. R. Carter. Cambridge: Cambridge UP. 158-167.

Kennedy, J. 1998. “On Edgar Allan Poe”. Gothic Horror. Ed. C. Bloom. London: MacMillan. 169-199.

Leary, L. 1961. Introduction. Home As Found. New York.

Leech, G. 1989. A Linguistic Guide to English Poetry. New York: Longman Group.

Mitchell, W.J.T., ed. 1980. The Language of Images. Chicago: University of Chicago Press.

Perry, M. 1979. "Literary dynamics: how the order of a text creates its meaning". Poetics Today I, I: 35-64 and 311-64.

Poe, E. A. 1986. The Fall of the House of Usher and Other Writings. Ed. D. Galloway. London: Penguin.

.1993. Tales of Mystery and Imagination. Hertfordshire: Wordsworth.

. 1996. El Gato Negro y Otros Cuentos de Horror. Ed. M Broncano. Barcelona: Vicens Vives.

Rimmon-Kenan, S. 1994. Narrative Fiction: Contemporary Poetics. London: Routledge.

Shklovsky, V. 1965. "Art as a technique". Russian Formalist Criticism: Four Essays. Eds. L. T. Lemon and M. J. Reis. Lincoln: University of Nebraska Press. 3-24.

Walker, I. 1993. "Edgar Allan Poe". American Literature to 1900. Ed. M. Cunlife. London: Penguin Books. 107-134.

Whitley, J. S. 1993. Introduction. Tales of Mystery and Imagination, by Edgar Allan Poe. Hertfordshire: Wordsworth. v-xiv. 